\title{
Surface water quality in canals in An Giang province, Viet Nam, from 2009 to 2016
}

\author{
Chất lượng nước mặt ở các kênh rạch nội đồng tỉnh An Giang, Việt Nam, giai đoạn 2009 đến \\ 2016
}

NGUYEN, Hong Thao Ly*; NGUYEN, Thanh Giao

Department of Environmental Management, College of Environment and Natural Resources, Can Tho University. 3/2 Street, Ninh Kieu District, Can Tho City, Viet Nam

\begin{abstract}
The present study evaluates the surface water quality in the canals of An Giang province in the period from 2009 to 2016. The results showed that surface water of the canals was contaminated by organic matter and microorganisms which makes it not suitable for water supply and conservation of aquatic life. The water quality parameters such as dissolved oxygen (DO), biological oxygen demand (BOD), total suspended solids (TSS), orthophosphate (P-PO ${ }_{4}^{3-}$ ) and coliforms levels in the wet season were found to be higher than those in the dry season. The problem of organic and microorganic pollution over a long period of time without solutions leads to declines in water quality and then quantity as well. Agriculture is the main activity contributing to pollution of surface water in interior canals along with the activities of daily life, industry and services. This causes pollution of the surface water on Hau River due to its exchange of water with the connected canals. Good agricultural practices should be implemented to limit the pollution of surface water resources of the Mekong Delta.
\end{abstract}

Nghiên cứu này nhằm đánh giá diễn biến chất lượng nước mặt trong các kênh rạch nội đồng của tỉnh An Giang trong giai đoạn 2009 - 2016. Kết quả cho thấy nước mặt tại các kênh rạch nội đồng đã ô nhiễm hữu cơ và vi sinh vật. Nguồn nước không phù hợp cho mục đích cấp nước sinh hoạt và bảo tồn thực vật thủy sinh. Các chỉ tiêu như hàm lượng oxy hòa tan (DO), nhu cầu oxy sinh hóa (BOD), tổng chất rắn lơ lửng (TSS), orthophosphate $\left(P-P_{4}{ }_{4}^{3-}\right)$ và coliforms trong mùa mưa cao hơn mùa khô. Vấn đề ô nhiễm hữu cơ và vi sinh vật diễn ra trong thời gian dài và chưa có giải pháp xử lý làm cho chất lượng nước suy giảm dẫn đến suy giảm về trữ lượng. Nông nghiệp là hoạt động chính góp phần làm ô nhiễm nguồn nước mặt trong các kênh rạch nội đồng bên cạnh các hoạt động sinh hoạt, công nghiệp và dịch vụ. Điều này dẫn đến nước mặt trên sông Hậu cũng có đặt tính ô nhiễm tương tự do trao đổi nước với các kênh rạch nội đồng. Thực hành sản xuất nông nghiệp thân thiện môi trường cần sớm được triển khai để hạn chế ô nhiếm nguồn nước mặt quan trọng của khu vực đồng bằng sông Cửu Long.

Keywords: coliforms; dissolved oxygen concentration; in-field canals; surface water quality; suspended solids

\section{Introduction}

An Giang is an upstream province of the Lower Mekong River System and one of the four key economic regions of Viet Nam. It has a unique hydrological regime and closely relies on Mekong river water regime with two major rivers: Tien river (80-km long) and Hau river (100-km long). The system of rivers and canals of the province has 280 routes with a general density of about $0.72 \mathrm{~km} / \mathrm{km}^{2}$, creating favorable conditions for the development of agricultural, industrial and service economy. In 2012, the agricultural production value of the province was over VND 8,000 billion and tends to increase over years (up to 2.3\% compared to that of 2011) (An Giang People's Committee, 2015). Average GDP growth rate was 8.63\% (period 2011-2015) (An Giang People's Committee, 2015). Along with the socio- economic development, water pollution has been increased. In agricultural production, due to abuse of plant protection chemicals or pesticides, polluted water sources in canals and ditches affect human health and environment. In aquaculture, due to mass farming, lack of planning, inappropriate following the technical processes, along with the large amount of feed used and improper feeding also causes contamination of water environment. Industrial zones are still in the development stage, factories and production facilities are still scattered and not concentrated in the industrial zones. As a result, untreated or improperly treated waste is one of the causes of water pollution in the rivers. In addition, domestic wastewater from rural to urban areas has not been planned for wastewater collection and treatment systems or the investment in construction of hydroelectric dams in the up- 
stream also contributes to a great impact on quality of surface water sources of the area. Field canals in An Giang province are directly affected by socio-economic development activities such as traditional villages and poor agricultural practices. This study aims to evaluate long-term surface water quality in the field canals in comparison with Hau river over eight-year period (2009-2016) to find out common and specific pollutants in some canals and river in An Giang province.

\section{Research methodology}

Monitoring data of eight years (2009-2016) on water quality in Hau river and field canals including $\mathrm{pH}$, temperature, total suspended solids (TSS), dissolved oxygen (DO), biochemical oxygen demand (BOD), nitrogen nitrate $\left(\mathrm{NO}_{3}{ }^{-} \mathrm{N}\right)$, orthophosphate $\left(\mathrm{PO}_{4}{ }^{3-}-\mathrm{P}\right)$, and coliforms were provided by An Giang Department of Natural Resources and Environment at 20 sampling locations which were shown in Figure 1 (see coordinates of the sampling locations in Table 1). The period of 2009-2016 was selected since the water quality parameters were regularly monitored three times per year (March, June, and September). The difference in mean values between the surface water quality parameters at the sampling sites was analyzed by one-way ANOVA using IBM SPSS statistics for Windows, version 20.0 (IBM Corp., 2011); Duncan was used to compare the difference in surface water quality parameters at a significance level of 5\% ( $p<0.05$ ) (Ahrari et al., 2015). Surface water quality parameters in the studied areas were compared with the National Technical Regulation on Surface Water Quality (QCVN 08-MT: 2015/ BTNMT).

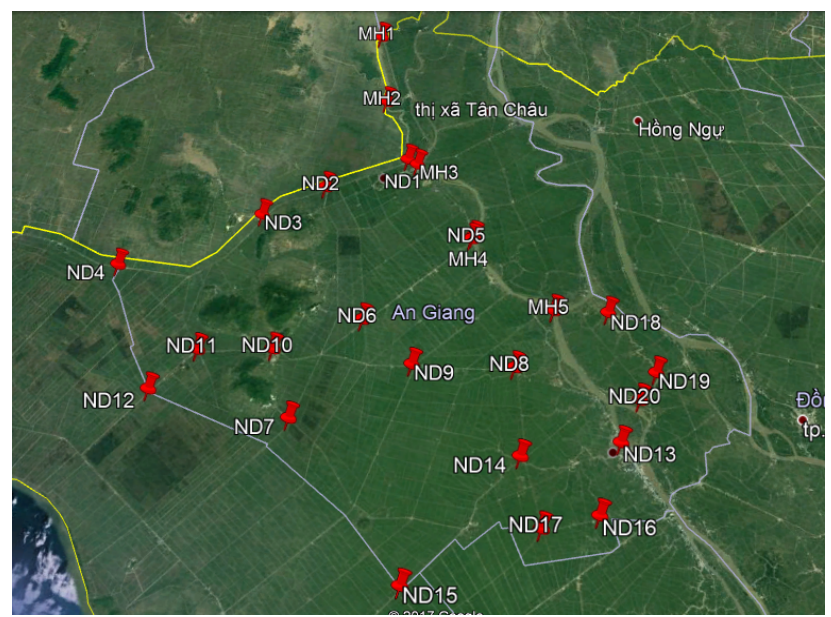

Figure 1. Locations of sampling sites of field canals and Hau river. ND1 belongs to Chau Doc town; ND2, ND3, and ND6 belong to Tinh Bien district; ND4, ND7, ND10, ND11 and ND12 belong to Tri Ton district; ND5 belong to Chau Phu district; ND8, ND9, ND14 belongs to Chau Thanh district; ND13 belongs to Long Xuyen city; ND15 belongs to Thoai Son district; ND18, ND19, ND20 belong to Cho Moi district; MH2MH6 belong to Hau River.
Table 1. Sampling sites of field canals and Hau river

\begin{tabular}{|c|c|c|}
\hline No. & Sampling site & Coordinates \\
\hline 1 & ND1 & $10^{\circ} 42^{\prime} 57.4^{\prime \prime} \mathrm{N} 105^{\circ} 06^{\prime} 37.1 " \mathrm{E}$ \\
\hline 2 & ND2 & $10^{\circ} 39^{\prime} 28.3^{\prime \prime N} 105^{\circ} 00^{\prime} 49.8^{\prime \prime E}$ \\
\hline 3 & ND3 & 10³6'17.7"N 10456'35.4"E \\
\hline 4 & ND4 & $10^{\circ} 30^{\prime} 21.3^{\prime \prime N} 104^{\circ} 46^{\prime} 56.5^{\prime \prime E}$ \\
\hline 5 & ND5 & $10^{\circ} 37^{\prime} 07.1 " \mathrm{~N} 105^{\circ} 12^{\prime} 39.0 " \mathrm{E}$ \\
\hline 6 & ND6 & $10^{\circ} 29^{\prime} 17.3^{\prime \prime} \mathrm{N} 105^{\circ} 05^{\prime} 54.6 " \mathrm{E}$ \\
\hline 7 & ND7 & $10^{\circ} 21^{\prime} 01.0^{\prime \prime} \mathrm{N} 105^{\circ} 02^{\prime} 18.5^{\prime \prime} \mathrm{E}$ \\
\hline 8 & ND8 & 10²7'35.6"N 105¹7'29.4"E \\
\hline 9 & ND9 & $10^{\circ} 26^{\prime} 31.1 " \mathrm{~N} 105^{\circ} 10^{\prime} 07.6 " \mathrm{E}$ \\
\hline 10 & ND10 & $10^{\circ} 25^{\prime} 52.8^{\prime \prime N} 104^{\circ} 59^{\prime} 57.9^{\prime \prime E}$ \\
\hline 11 & ND11 & $10^{\circ} 24^{\prime} 52.4^{\prime \prime} \mathrm{N} 104^{\circ} 54^{\prime} 35.0^{\prime \prime} \mathrm{E}$ \\
\hline 12 & ND12 & $10^{\circ} 21^{\prime} 20.3^{\prime \prime N} 104^{\circ} 51^{\prime} 54.3 " \mathrm{E}$ \\
\hline 13 & ND13 & $10^{\circ} 23^{\prime} 26.6^{\prime \prime} \mathrm{N} 105^{\circ} 25^{\prime} 42.8^{\prime \prime E}$ \\
\hline 14 & ND14 & $10^{\circ} 21^{\prime} 13.0^{\prime \prime} \mathrm{N} 105^{\circ} 18^{\prime} 54.0^{\prime \prime E}$ \\
\hline 15 & ND15 & $10^{\circ} 11^{\prime} 01.2^{\prime \prime N} 105^{\circ} 12^{\prime} 21.5^{\prime \prime E}$ \\
\hline 16 & ND16 & $10^{\circ} 18^{\prime} 04.5^{\prime \prime} \mathrm{N} 105^{\circ} 24^{\prime} 55.1$ "E \\
\hline 17 & ND17 & 10॰16'29.6"N 105²1'06.8"E \\
\hline 18 & ND18 & $10^{\circ} 33^{\prime} 00.5^{\prime \prime} \mathrm{N} 105^{\circ} 23^{\prime} 34.7^{\prime \prime E}$ \\
\hline 19 & ND19 & $10^{\circ} 29^{\prime} 00.8^{\prime \prime N} 105^{\circ} 27^{\prime} 34.4^{\prime \prime E}$ \\
\hline 20 & ND20 & $10^{\circ} 26^{\prime} 47.1 " \mathrm{~N} 105^{\circ} 26^{\prime} 40.2^{\prime \prime E}$ \\
\hline 21 & $\mathrm{MH} 1$ & $10^{\circ} 53^{\prime} 47.3^{\prime \prime} \mathrm{N} 105^{\circ} 02^{\prime} 15.8^{\prime \prime} \mathrm{E}$ \\
\hline 22 & $\mathrm{MH} 2$ & $10^{\circ} 47^{\prime} 48.6^{\prime \prime N} 105^{\circ} 03^{\prime} 55.4^{\prime \prime E}$ \\
\hline 23 & $\mathrm{MH3}$ & $10^{\circ} 42^{\prime} 39.6^{\prime \prime N} 105^{\circ} 07^{\prime} 25.0^{\prime \prime E}$ \\
\hline 24 & $\mathrm{MH} 4$ & $10^{\circ} 37^{\prime} 20.7^{\prime \prime N} 105^{\circ} 12^{\prime} 46.3 " \mathrm{E}$ \\
\hline 25 & MH5 & 10³2'27.6"N 105¹9'37.0"E \\
\hline
\end{tabular}

\section{Results and discussion}

\subsection{Temperature}

Water temperature in the field canals ranged from 28.1 to $31.3^{\circ} \mathrm{C}$, the highest temperature was found in Long Xuyen area $\left(31.3 \pm 2.0^{\circ} \mathrm{C}\right.$ in 2010$)$ and the lowest was in Chau Doc area $\left(28.1 \pm 0.9^{\circ} \mathrm{C}\right.$ in 2014$)$. The water temperature in Hau River ranged from 27.7 to $31.6^{\circ} \mathrm{C}$, the highest temperature was in $2009\left(31.0 \pm 1.0^{\circ} \mathrm{C}\right)$ and the lowest in $2015(28.7 \pm$ $1.9^{\circ} \mathrm{C}$ ). Water temperatures in the dry season were in the range of $29.5-30.6^{\circ} \mathrm{C}$ which were higher than those in the rainy season $\left(28.6-29.7^{\circ} \mathrm{C}\right.$ ) (Figure 2). Average temperature was lowest in Cho Moi area $\left(28.6^{\circ} \mathrm{C}\right)$ and the highest in Hau river $\left(30.6^{\circ} \mathrm{C}\right)$. The temperature difference between Hau river and the field canals in An Giang province during rainy season and dry season was approximate $2.1^{\circ} \mathrm{C}$. Average water temperature over years in the field canals and Hau River (Figure 3) showed that the temperature fluctuated between $29-30^{\circ} \mathrm{C}$, averaged at $29.7 \pm 0.7^{\circ} \mathrm{C}$. There was a significant difference $(p<0.05)$ in temperatures among Chau Phu and Tri Ton, Chau Thanh, Long Xuyen, Thoai Son, and Hau river (Figure 3). 


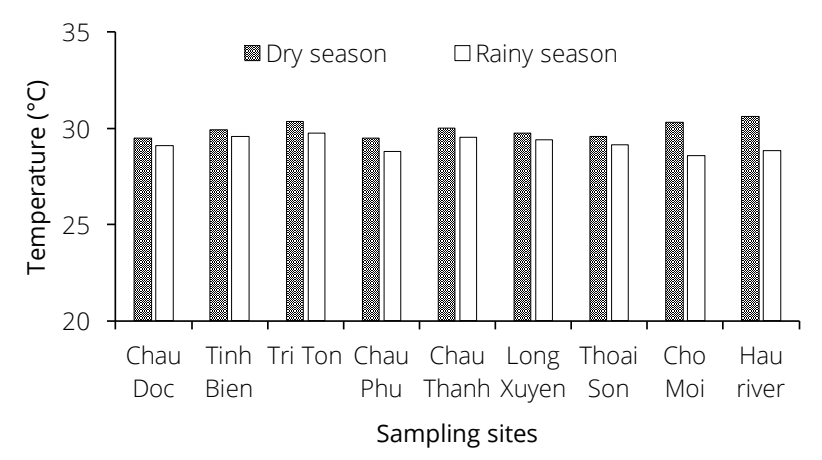

Figure 2. Seasonal and spatial fluctuation of water temperature from 2009 to 2016 (mean values)

Generally, the temperature fluctuation in the canals was small and was in accordance with the temperature of the region since water has the function of regulating the temperature, especially in the large and depth canals or rivers (Hoc, 2011). This temperature range of the river and canals is favorable for aquatic life (Phu and Ut, 2006).

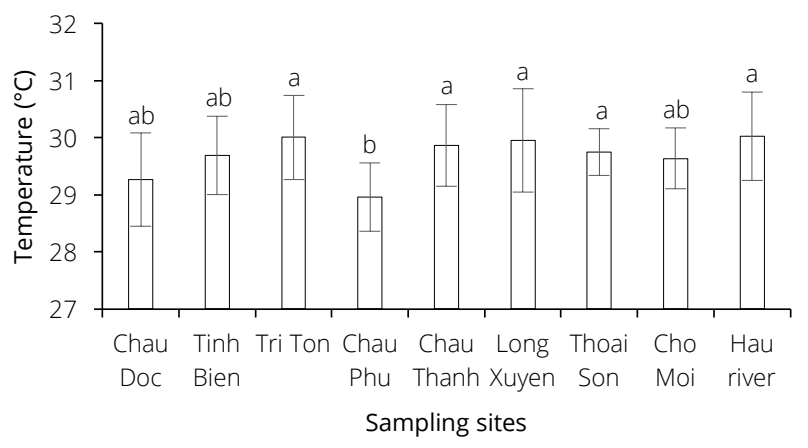

Figure 3. The mean temperatures at different sampling sites over the period of 2009-2016. The different letters indicate statistically significantly different at $\alpha=5 \%$

\section{$3.2 \mathrm{pH}$ values}

It was found that $\mathrm{pH}$ values in the dry season and rainy season at all sites ranged from 6.9 to 7.1, indicating a very small seasonal and spatial fluctuation over the period of eight years (Figure 4).

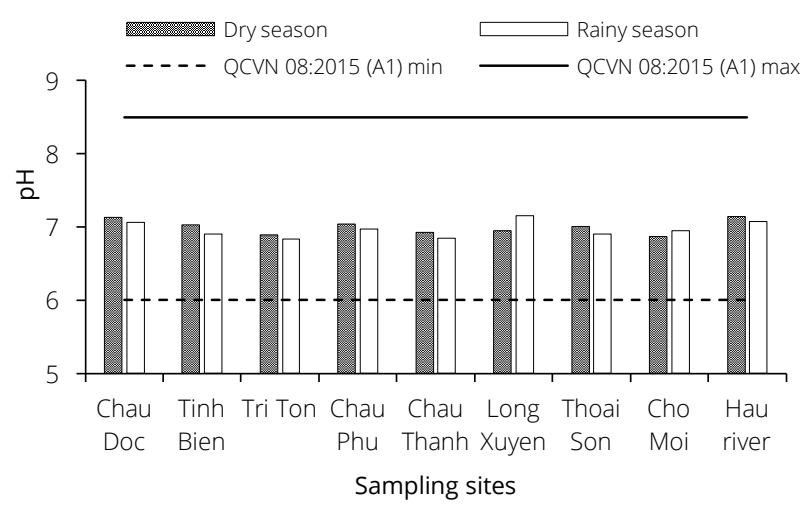

Figure 4. Seasonal and spatial fluctuation of $\mathrm{pH}$ of water from 2009 to 2016

As indicated in Figure 5, the mean $\mathrm{pH}$ values over the years in the study areas varied from 6.7 to 7.1 , with an average value of $7.0 \pm 0.2$. The $\mathrm{pH}$ value in Tri Ton area was significantly different from that of Chau Doc, Chau Phu, Long Xuyen, Thoai Son and Hau river $(p<0.05)$. The $\mathrm{pH}$ of the canals was in line with the one regulated in the National Technical Standard on Surface Water Quality (QCVN 08MT: 2015/BTNMT).

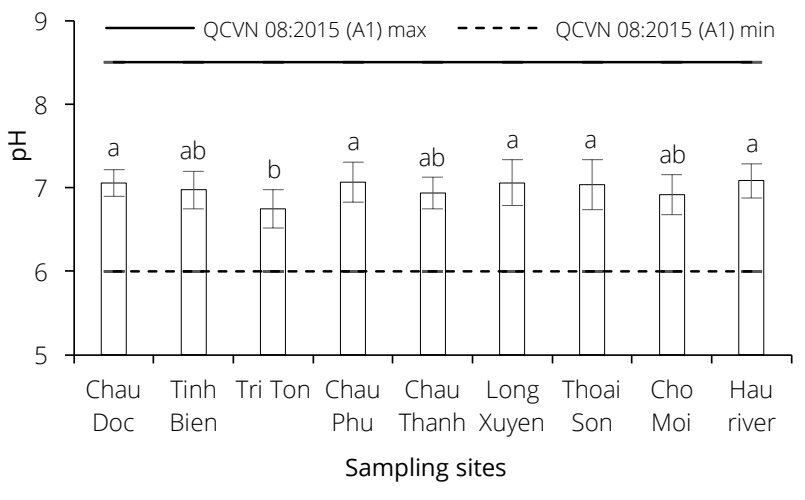

Figure 5. The mean $\mathrm{pH}$ at different sampling sites over the period of 2009-2016. The different letters indicate statistically significantly different at $\alpha=5 \%$

\subsection{Total suspended solids}

Total suspended solids (TSS) in the field canals tended to increase over time and exceeded the limit allowed under QCVN 08-MT: 2015/BTNMT. In all surveyed sites, TSS ranged from 25.0 to $93.7 \mathrm{mg} / \mathrm{L}$ in which the lowest concentration (25.0 $\pm 11.5 \mathrm{mg} / \mathrm{L})$ was found in 2011 and the highest concentration $(93.7 \pm 28.3 \mathrm{mg} / \mathrm{L})$ was measured in Tri Ton in 2015. The lowest and highest concentrations exceeded permissible standard by 1.25 and 4.7 times, respectively. The concentration of TSS in Hau River ranged from 40.1-68.0 $\mathrm{mg} / \mathrm{L}$, which exceeded the allowed standard from 2 to 3.4 times.
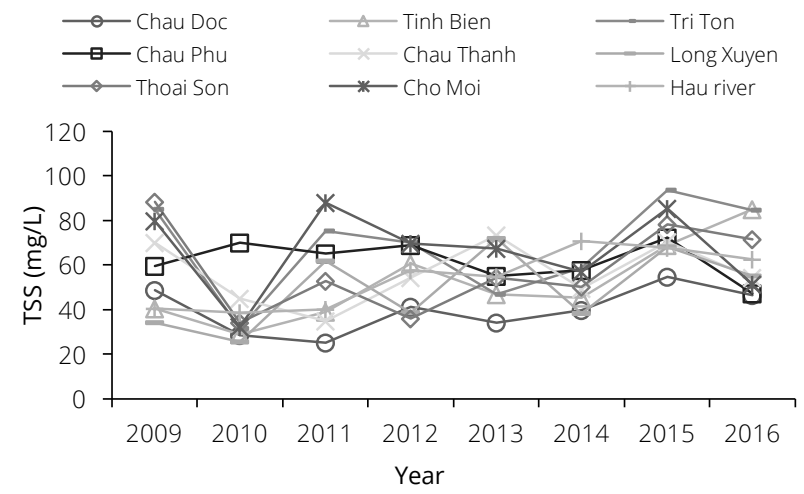

Figure 6. The trend TSS from 2009 to 2016 . The yearly average of TSS was calculated from the data of three months including March, June and September

It can be seen from Figure 6 that TSS values of the canals (smaller rivers) tended to be higher than those in Hau River (large river). The difference could possibly be caused by the difference in flow rate and water volume between the small and large rivers. In addition, these field canals also directly 
receive wastewater from agricultural production, surplus feeding from aquaculture and domestic wastewater.

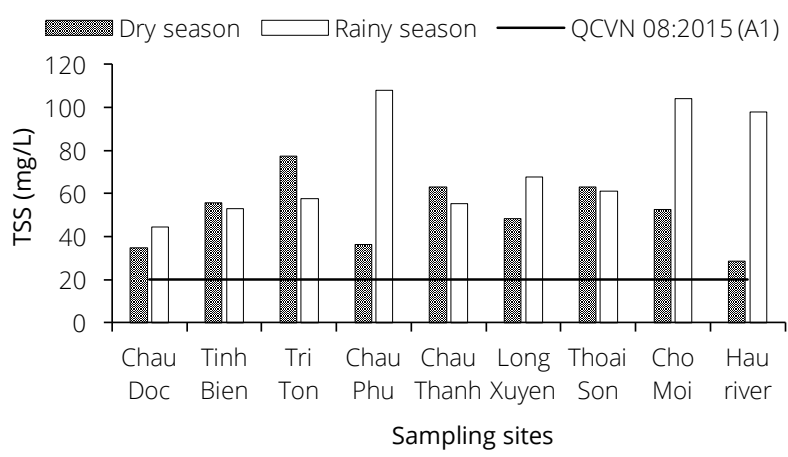

Figure 7. Seasonal and spatial fluctuation of TSS from 2009 to 2016 (mean values)

Total suspended solids have shown a significant difference between dry season and rainy season (Figure 7) in most surveyed sites. In rainy season, TSS increased dramatically which could be due to high rainfall leading to run-off carrying eroded matters into the river. In addition, materials washed away from the river banks also contributed to the increase of suspended solids. The highest TSS concentration was found in Chau Phu (107.8 mg/L) in rainy season and the lowest one was recorded in Hau river $(28.4 \mathrm{mg} / \mathrm{L}$ ) in dry season. The averaged values of TSS over eight years indicated that TSS was found highest in Tri Ton (68.3 \pm 21.2 $\mathrm{mg} / \mathrm{L})$, and lowest in Chau Doc $(39.8 \pm 10.1 \mathrm{mg} / \mathrm{L})$, and they were distinctively differed with the other sites $(p<0.05)$ (Figure 8).

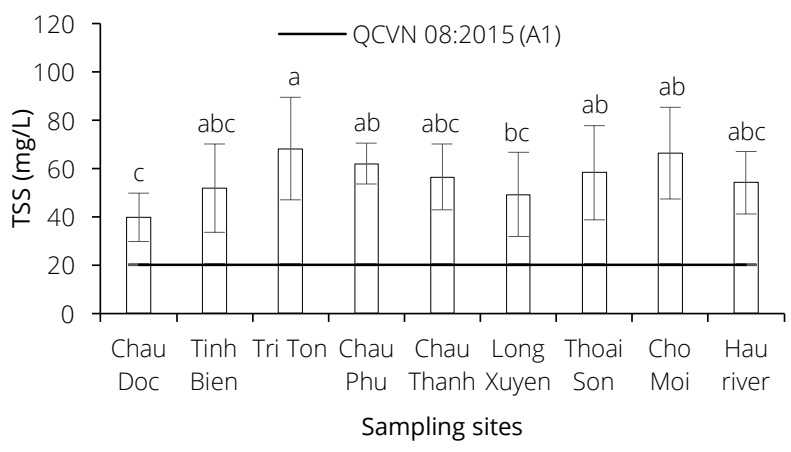

Figure 8. The mean TSS at different sampling sites over the period of 2009-2016. The different letters indicate statistically significantly different at $\alpha=5 \%$

\subsection{Dissolved oxygen}

As depicted in Figure 9, the dissolved oxygen (DO) concentration varied unevenly and tended to increase in the period of 2011-2012 and gradually decreased in the period of 2014-2016. DO varied from 3.2-6.3 mg/L over the eight years period at all sampling sites. The highest value of DO was measured in Chau Phu $(6.3 \pm 1.1 \mathrm{mg} / \mathrm{L})$ in 2012 and the lowest was found in Thoai Son (3.2 $\pm 1.3 \mathrm{mg} / \mathrm{L}$ ) in 2010. DO values at all sites were lower than the permitted level of QCVN 08-MT: 2015/BTNMT except in Chau Phu area (2012) and Hau river (2014).

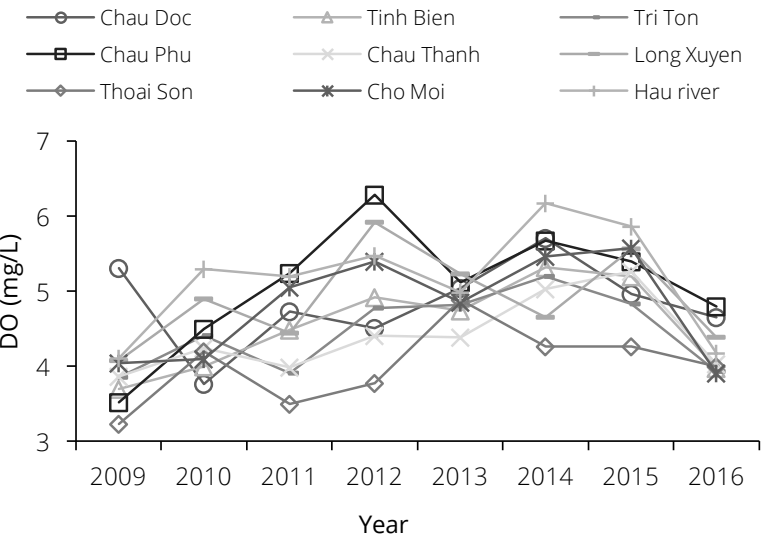

Figure 9. The trend DO from 2009 to 2016. The yearly average of DO was calculated from the data of three months including March, June and September

Mean DO in the rainy season and dry season in Hau river and in the field canals were $5.5 \mathrm{mg} / \mathrm{L}$ and $4.9 \mathrm{mg} / \mathrm{L} ; 5.3$ $\mathrm{mg} / \mathrm{L}$ and $4.1 \mathrm{mg} / \mathrm{L}$, respectively. The values of $\mathrm{DO}$ in the rainy season were higher than those in the dry season in all study sites (Figure 10). The finding in this study was in consistence with the prior study which found that the DO concentration in the rainy season was usually higher than in the dry season due to the lower organic content of the rainy season and slower oxidation rates in the dry season (Sansanayuth et al., 1996). The former study also found that DO concentrations in rainy season were higher than those in dry season in most surveyed areas in Hau river (Lien et al., 2016).

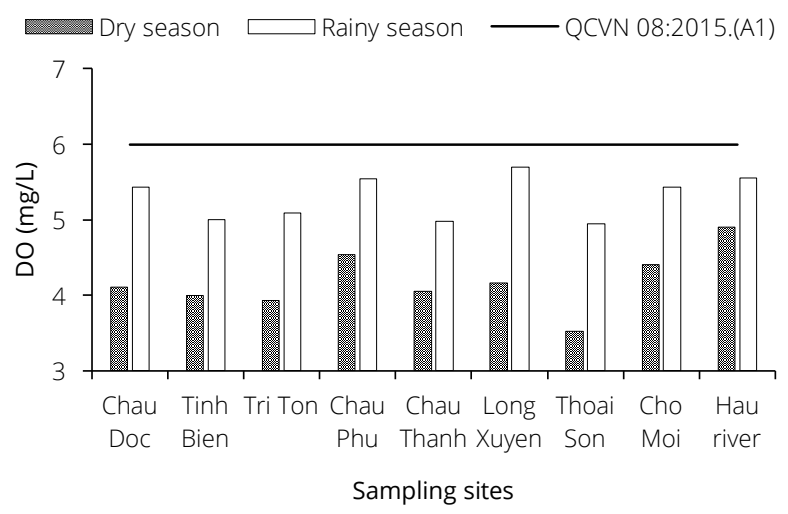

Figure 10. Seasonal and spatial fluctuation of DO from 2009 to 2016 (mean values)

Average DO over the period of 2009-2016 (Figure 11) showed that the DO at the survey sites ranged from 4.0 to $5.2 \mathrm{mg} / \mathrm{L}$ and this range was below the allowable threshold of the standard. According to QCVN 08-MT: 2015/BTNMT on surface water quality and Ongley (2009), the limit of DO concentration for aquatic life in the Lower Mekong Basin must be $5 \mathrm{mg} / \mathrm{L}$ or higher. The DO range in this study suggested that DO concentrations were relatively lower than the one needed for aquatic life reflecting organically polluted water environment. In general, the DO concentration in Hau river tended to be higher than those in the field connected canals and this could be because the in-field rivers 
directly received wastewater containing rich organic matters from agricultural production and daily activities. The decomposition of organic matters consumes dissolved oxygen, thereby reducing DO in water.

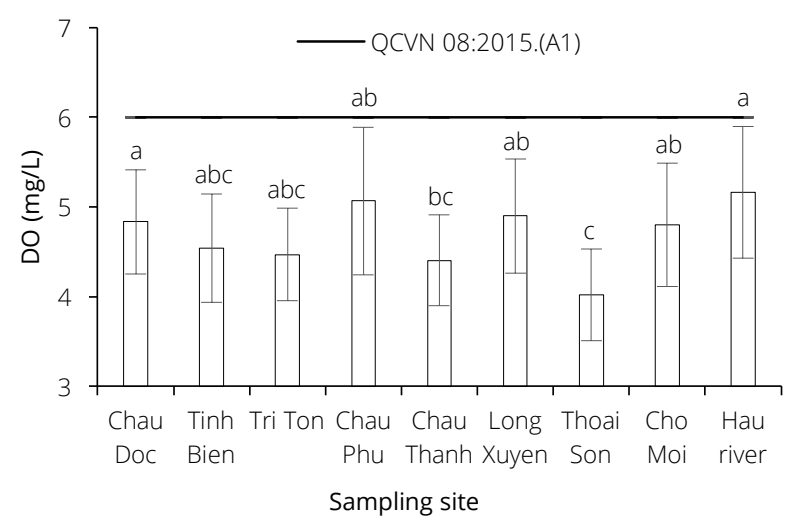

Figure 11. The mean DO at different sampling sites over the period of 2009-2016. The different letters indicate statistically significantly different at $\alpha=5 \%$

\subsection{Biological oxygen demand}

The analysis of the monitoring results indicated that biological oxygen demand (BOD) values in the field-connected canals were relatively low in fluctuation at the surveyed sites (Figure 12). The highest BOD concentration in Chau Phu area was $12.3 \pm 9.2 \mathrm{mg} / \mathrm{L}$ (in 2012), the lowest ones in the areas of Long Xuyen ( $4.7 \pm 1.2 \mathrm{mg} / \mathrm{L}$ in 2009), and Chau Thanh ( $4.7 \pm 2.3 \mathrm{mg} / \mathrm{L}$ in 2010). It was clearly indicated that BOD at all monitoring points exceeded the limit allowed by QCVN 08-MT: 2015/BTNMT. BOD in Hau River has not been changed significantly over the years except for 2011, which has suddenly surpassed the standard of QCVN 08MT: 2015/BTNMT. BOD values in the Hau river and field canals were not much difference and they tended to increase over the years indicating increasing discharge of organic wastes into the receiving rivers.

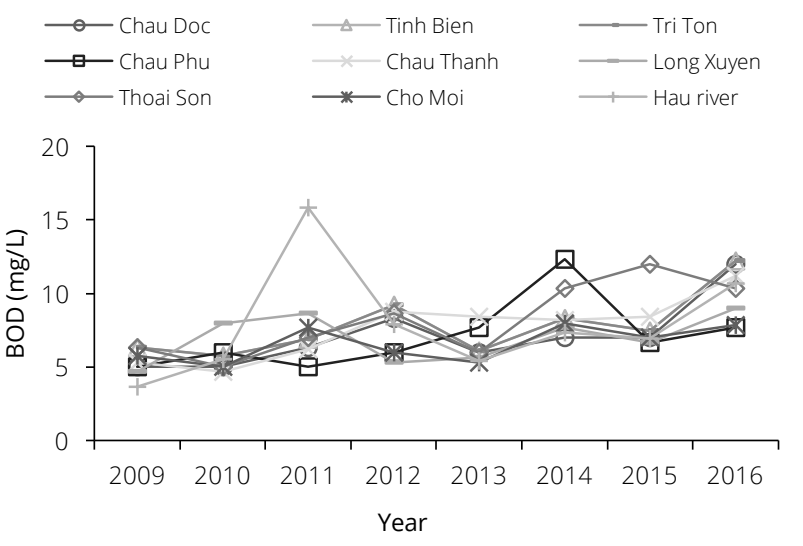

Figure 12. The trend BOD from 2009 to 2016 . The yearly average of BOD was calculated from the data of three months including March, June and September

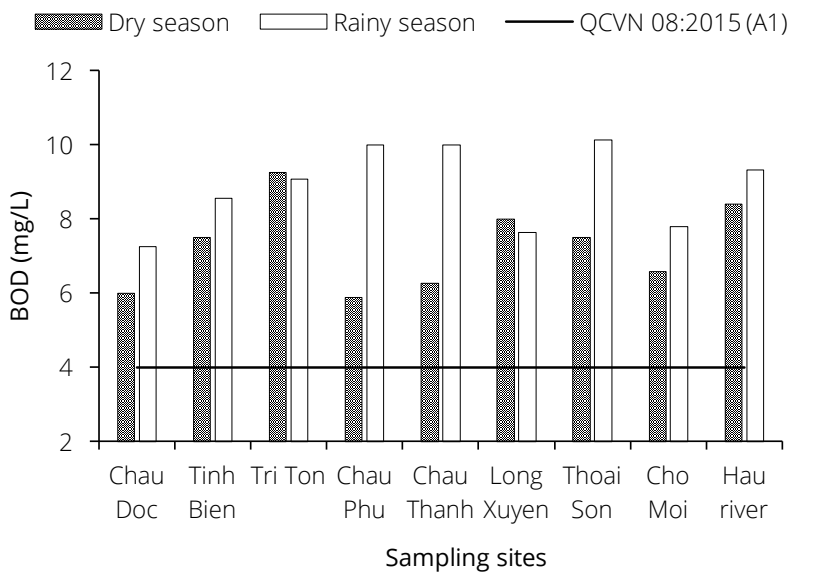

Figure 13. Seasonal and spatial fluctuation of BOD from 2009 to 2016 (mean values)

Figure 13 shows that the average BOD concentrations in rainy season and dry season in Hau River were $5.5 \mathrm{mg} / \mathrm{L}$ and $4.9 \mathrm{mg} / \mathrm{L}$, respectively, and field canals were $5.3 \mathrm{mg} / \mathrm{L}$ and $4.1 \mathrm{mg} / \mathrm{L}$ respectively. As can be seen that BOD in rainy season was generally higher than that in dry season at all sites. From Figure 14, the average BOD values over the period of eight years in the study sites varied between $6.6 \pm$ 1.2 and $8.2 \pm 2.5 \mathrm{mg} / \mathrm{L}$, reaching the mean value of $7.4 \pm$ $2.2 \mathrm{mg} / \mathrm{L}$. BOD values were relatively stable but they exceeded the permitted level of QCVN 08-MT: 2015/BTNMT from 1.2 to 1.6 times. This indicated that the water quality in the study areas is permanently organically contaminated.

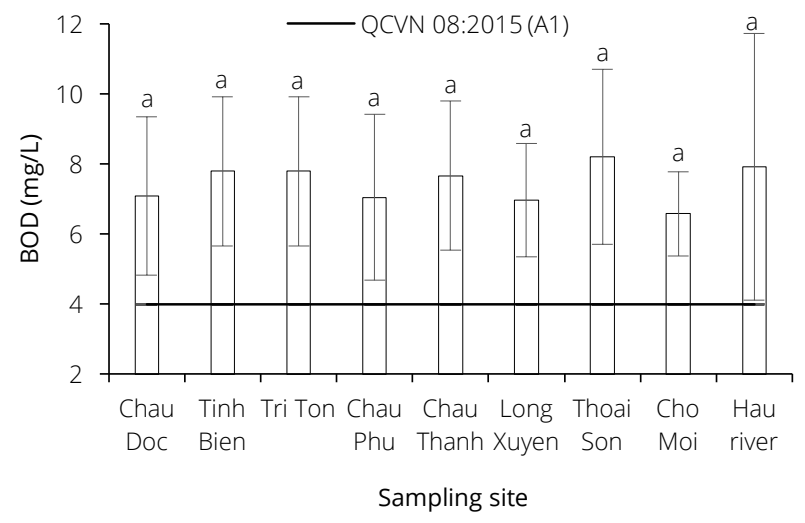

Figure 14. The mean BOD at different sampling sites over the period of 2009-2016. The different letters indicate statistically significantly different at $\alpha=5 \%$

\subsection{Nitrate}

Nitrate $\left(\mathrm{N}-\mathrm{NO}_{3}{ }^{-}\right)$concentrations in the field canals were highly fluctuated in the range of 0.03-1.76 mg/L. The highest value was found in Thoai Son $(1.79 \pm 1,06 \mathrm{mg} / \mathrm{L})$ while the lowest value was found in Chau Phu $(0.03 \pm 0.04 \mathrm{mg} / \mathrm{L})$. Nitrate in Hau River ranged from $0.05 \pm 0.03$ to $1.45 \pm 1.02$ $\mathrm{mg} / \mathrm{L}$. Monitoring results indicated that nitrate concentration did not exceed the permissible limit of QCVN 08-MT: 2015/BTNMT. The nitrate concentration at the survey sites was seasonally fluctuated (Figure 15). Generally, the nitrate 
values in the dry season were higher than those in the rainy season at all sites.

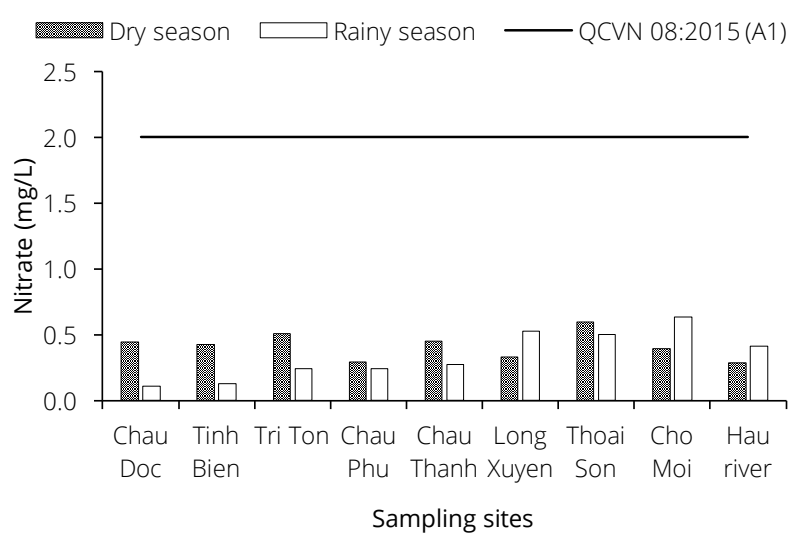

Figure 15. Seasonal and spatial fluctuation of $\mathrm{N}^{-\mathrm{NO}_{3}}{ }^{-}$from 2009 to 2016 (mean values)

Figure 16 indicated that the averaged nitrate of eight years at the sampling sites varied from $0.31 \pm 0.3$ to $0.58 \pm 0.64$ $\mathrm{mg} / \mathrm{L}$. The nitrate concentrations were low and they were not significantly different ( $p>0.05)$ among the sites. The nitrate concentrations were in line with the permitted value of the National Technical Regulation on Surface Water Quality (QCVN 08-MT: 2015/BTNMT). According to Ongley (2009) the concentration of ${\mathrm{N}-\mathrm{NO}_{3}}^{-}>0.7 \mathrm{mg} / \mathrm{L}$ would be highly potential for algae bloom. According to

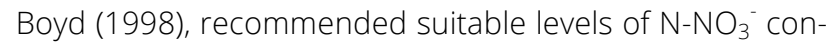
centration for aquaculture range from 0.2 to $10 \mathrm{mg} / \mathrm{L}$. it could be concluded that there was no risk of human health and ecosystems associated with nitrate.

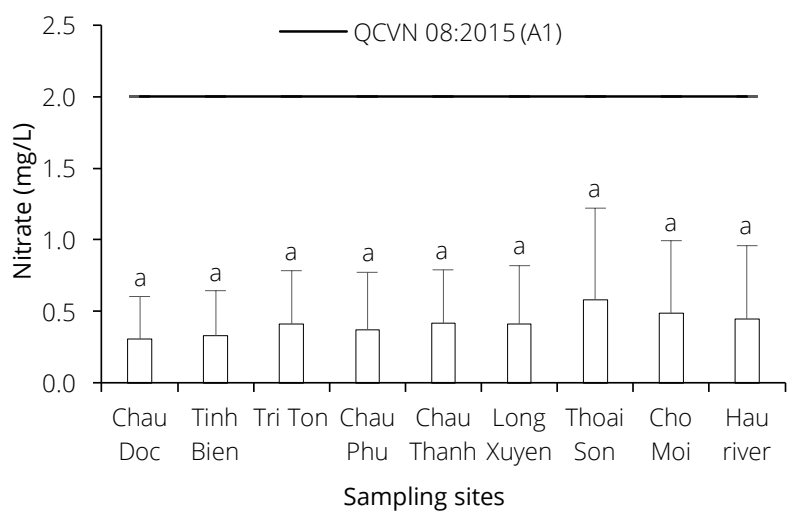

Figure 16. The mean nitrate at different sampling sites over the period of 2009-2016. The different letters indicate statistically significantly different at $\alpha=5 \%$

\subsection{Orthophosphate}

The results showed that orthophosphate concentration ( $P$ $\mathrm{PO}_{4}{ }^{3-}$ ) at the sites in the field canal varied from 0.02 to 0.47 $\mathrm{mg} / \mathrm{L}$, averaged at $0.16 \pm 0.12 \mathrm{mg} / \mathrm{L}$. The phosphorus concentrations between the dry and the wet seasons (Figure 17) at the monitoring points were slightly differed in which orthophosphate in rainy season was higher than that in dry season except for Cho Moi area. The orthophosphate concentration in Hau river was lower than those in the in-field canals. This could be because of volume of water and fertilizers used in agricultural practices and other activities.

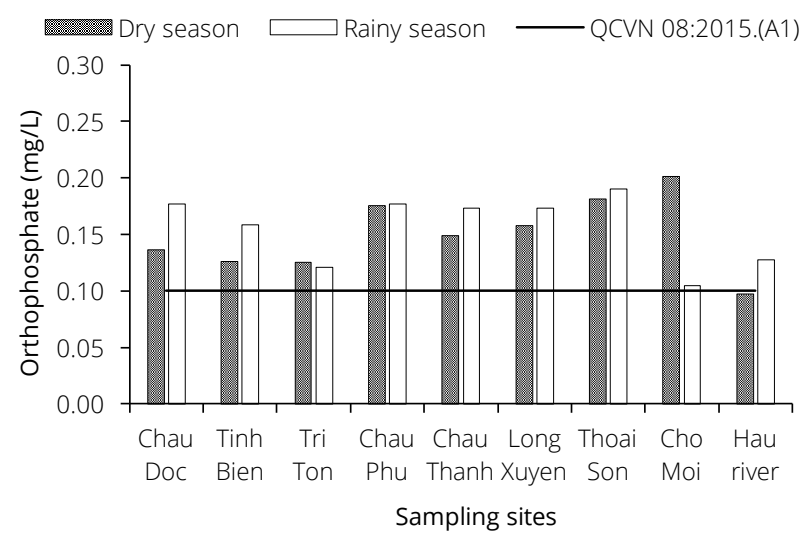

Figure 17. Seasonal and spatial fluctuation of orthophosphate from 2009 to 2016 (mean values)

The average concentrations of orthophosphate in the study sites for the period 2009-2016 (Figure 18) showed that there was not significantly different among the study sites ( $p>0.05$ ). However, phosphorus at the monitoring points exceeded the permitted level of QCVN 08-MT: 2015/BTNMT. The present study indicated that orthophosphate could be the problem for water quality in the river system in An Giang province.

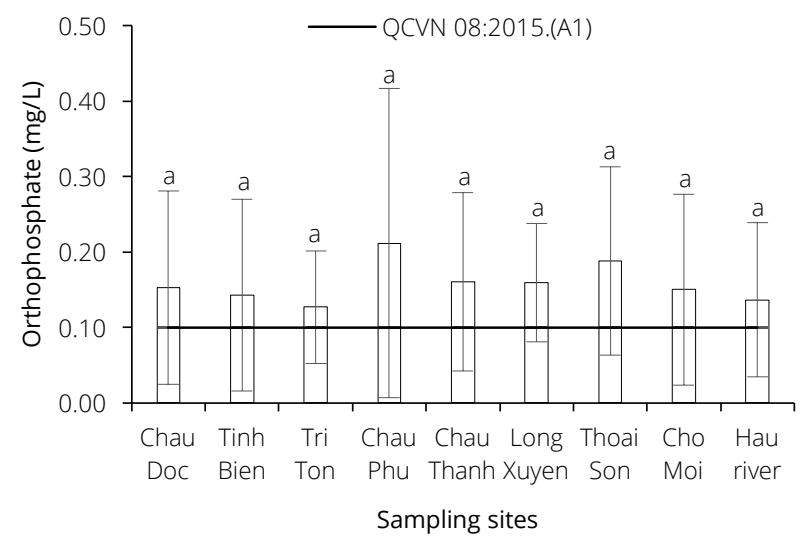

Figure 18. The mean orthophosphate concentration at different sampling sites over the period of 2009-2016. The different letters indicate statistically significantly different at $a$ $=5 \%$

\subsection{Coliforms}

The mean densities of coliforms in the field canals ranged from 2.26E+03 to 1.55E+05 MPN/100 mL Coliforms density in Hau River ranged from 5.36E+03 to $1.76 \mathrm{E}+04$, exceeding 2.14-7.04 times compared to permitted threshold regulated in QCVN 08-MT: 2015/BTNMT. Coliforms are the water quality indicator that is used to evaluate the quality of natural water. The presence of coliforms indicated that the water has been contaminated by organic matters originating from human and animal wastes. 


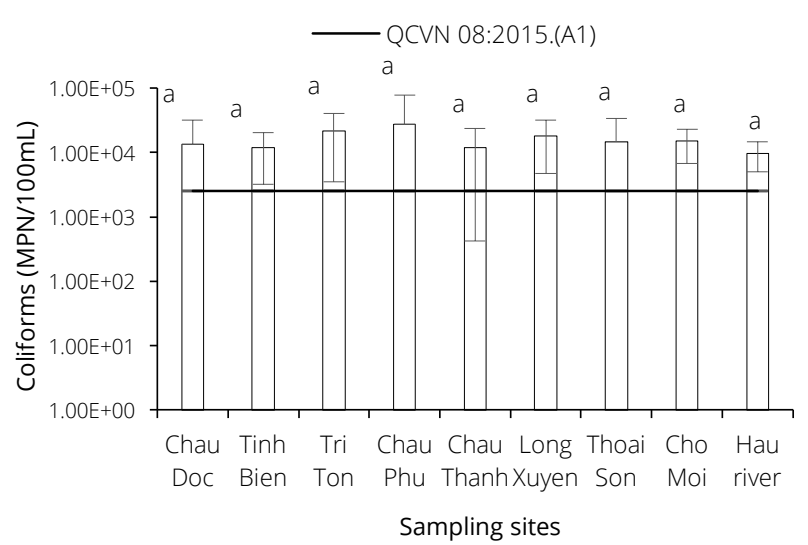

Figure 19. The mean coliforms density at different sampling sites over the period of 2009-2016. The different letters indicate statistically significantly different at $\alpha=5 \%$

\section{Conclusion}

This study indicated that surface water quality of the infield canals and Hau river in An Giang province for the period 2009-2016 showed signs of organic and microbial contamination, not meeting the permitted surface water quality for the purpose of domestic water supply, and aquatic life as stated in the national technical standard of QCVN 08-MT:2015/BTNMT. The pollution of the field canals was more serious than that in Hau river which could be attributed to the size of the rivers. The surface water quality parameters such as DO, BOD, TSS, orthophosphate and coliforms tended to be higher during the rainy season indicating their seasonal variations. The practice of environmentally friendly agriculture should be implemented as soon as possible to limit the pollution of surface water resources of the Mekong Delta.

Acknowledgement. The author would like to thank for the data provision from Department of Natural Resources and Environment of An Giang province. Any opinions, findings, and conclusions or recommendations expressed in this material are those of the author and does not necessarily reflect the views of any agencies.

\section{References}

[1] Ahrari, F., Eslami, N., Rajabi, O., Ghazvini, K., Barati, S. 2015. The antimicrobial sensitivity of Streptococcus mutans and Streptococcus sangius to colloidal solutions of different nanoparticles applied as mouthwashes. Dental Research Journal 12: 44-49.

[2] Boyd, C.E. 1998. Water quality for pond aquaculture. Research and Development Series. International Center for Aquaculture and Aquatic Environments, Auburn University, $37 \mathrm{pp}$.

[3] Duyen, P.L.M., Toan, M.V., Tri, V.P.D., Chiem, N.H., 2015. Surface water quality and self-cleaning ability of the canal system in the closed dike area in My Luong town, Cho Moi district, An Giang province. Can Tho University Journal of Science, 39: 97-104 (in Vietnamese).

[4] IBM Corp. 2011. IBM SPSS Statistics for Windows, Version 20.0. Armonk, NY: IBM Corp.

[5] Lien, N.T.K, Huy, L.Q, Oanh, D.T.H, Phu, T.Q., Ut, V.N. 2016. Water quality in main rivers and tributaries of the Hau River. Can Tho University Journal of Science, 43: 68-79 (in Vietnamese).

[6] Ongley. E.D. 2009. Chapter 12: Water Quality of the Lower Mekong River. In: Campbell, I.C. (ed.): The Mekong: Biophysical Environment of an International River Basin. Academic Press, 4951 Connaught Ave., Montreal, QC, Canada H4V 1X4, 297-320. ISBN 978-012-374026-7.

[7] People's Committee of An Giang province, 2015. Report on the state of environment in five years (2011 2015) of An Giang province, 181 pp (in Vietnamese).

[8] Phu, T.Q, Ut, V.N. 2006. Water quality for pond aquaculture. Can Tho University. College of Aquaculture and Fisheries. 199 pp (in Vietnamese).

[9] QCVN 08-MT:2015/BTNMT (2015) National technical regulation on surface water quality.

[10] Sansanayuth, P., Phadungchep, A., Ngammontha, S., Ngdngam, S., Sukasem, P., Hoshino, H., Ttabucanon, M.S. 1996. Shrimp pond effluent: pollution problems and treatment by constructed wetlands. Water Science and Technology, 34 (11): 93-98. 